Article

\title{
The Impact of Surface Preparation for Self-Compacting, High-Performance, Fiber-Reinforced Concrete Confined with CFRP Using a Cement Matrix
}

\author{
Krzysztof Adam Ostrowski ${ }^{1, *(1)}$, Roman Kinasz ${ }^{2}\left(\mathbb{D}\right.$ and Piotr Dybet ${ }^{2}(\mathbb{C}$ \\ 1 Institute of Building Materials and Structures, Cracow University of Technology, 24 Warszawska Str., \\ 31-155 Cracow, Poland \\ 2 Faculty of Mining and Geoengineering, AGH University of Science and Technology, 30 Adama Mickiewicza \\ Str., 30-059 Cracow, Poland; rkinash@agh.edu.pl (R.K.); dybel@agh.edu.pl (P.D.) \\ * Correspondence: krzysztof.ostrowski.1@pk.edu.pl; Tel.: +48-12-628-2313
}

Received: 30 May 2020; Accepted: 22 June 2020; Published: 24 June 2020

check for updates

\begin{abstract}
With the development of concrete technology, the tendency to combine different materials with each other to achieve a greater efficiency and durability of structures can be observed. In the modern construction industry, various materials and techniques are increasingly being combined in order to achieve e.g., an increased resistance to dynamic impacts of a structure, or an increased scope of work of a selected constructional element, which translates into a significant increase in the energy of destruction. Thus, hybrid elements, known as composite ones, are created, which consist of concrete and reinforcements. This study examined the influence of the preparation of the concrete surface on the behavior of high-performance, self-compacting, fiber-reinforced concrete (HPSCFRC), reinforced with carbon fibers (CF) using a cement matrix. In the general lamination processes, this is preformed using epoxy resin. However, epoxy resin is sensitive to relatively low temperatures, and therefore the authors attempted to use a cement matrix in the lamination process. When connecting hardened concrete with a fresh concrete matrix or mixture, the type of the concrete surface is significant. In this research, three types of concrete surfaces e.g., unprepared, sanded and grinded were considered. All of the surfaces were examined using a 3D laser scanner, to determine the Abbott-Firestone profile material share curve. In this research, cylindrical concrete specimens were reinforced with one, two and three layers of laminates. They were then subjected to a uniaxial compressive test. The results of tests showed that the use of cement matrix in the lamination process, due to its low efficiency, should not be applied when reinforcing concrete elements with a high compressive strength. Moreover, the grinded surface of concrete showed the best cooperation with CF reinforcement.
\end{abstract}

Keywords: concrete surface; CFRP; cement matrix; high-performance self-compacting fiber reinforced concrete; stress-strain characteristic; reinforcement

\section{Introduction}

Composites (combined materials) are materials that are consciously constructed of two or more materials and which have properties other than individual constituent materials. Fiber reinforced polymer (FRP) composite can be defined as a polymer which is reinforced with fiber. The use of FRP in civil engineering is becoming more and more common in relation to strengthening existing and newly designed structures. This is due to the many advantages of materials from this group of polymers. The most important advantages of FRP materials are its: high Young modulus, strength to weight ratio, 
resistance to aggressive environments, good fatigue properties, low lifecycle costs, electromagnetic transparency and low thermal conductivity [1-7].

In civil engineering, intensive growth in the design of structures manufactured by self-compacting concrete (SCC) has been observed [8,9]. The use of classic unmodified concrete in some types of building structures is not sufficient today. Requirements for structures in terms of bearing capacity and serviceability are increasing, and their fulfillment using ordinary concrete becomes uneconomical and even impossible in some cases. This forced the search for new ways to improve the properties of concrete. Thanks to the development of material engineering, a "new class of concrete" has emerged called fiber-reinforced concrete [10,11]. A high compressive strength, characteristic rheological properties of the fresh concrete mixture and quasi-plastic stress-strain curve are specific for high-performance self-compacting fiber-reinforced concrete (HPSCFRC). The usage of steel fiber into the structure of concrete is essential to obtain high ductility and strength of this specific kind of construction material [12-17].

Carbon fibers (CF) are the most often used to strengthen engineering structures, and are characterized by good thermal and chemical resistance. Working temperature is one of the most important criteria for choosing a given type of fiber to reinforce a composite material. For example, the properties of carbon fibers do not change in a non-oxidizing atmosphere to $2000{ }^{\circ} \mathrm{C}$, unlike glass or aramid fibers $[18,19]$. Carbon fibre reinforced polymer (CFRP) materials are commonly used to reinforced variety type of structures in civil engineering. However, this technique is a relatively expensive but effective solution [20]. In case of concrete studies, CFRP is often considered as an effective and alternative technique to reinforce many types of concrete or masonry structures incorporating old structures and monuments [21-23]. In general, the current literature contains a lot of research that relates to concrete reinforcement with CFRP in various types of samples, such as classic columns [24], elements with CFRP material in cavities of concrete surfaces [25] and concrete columns under eccentric load [26]. The development of CFRP techniques can also be observed in case of beam structures. Zaki et al. [27] proposed CFRP fiber anchors as a reinforcement of T-shaped beams. Zhang et al. [28] proposed the use of stirrups from CFRP to reinforce concrete beams made of reinforced aggregate concrete from recycled aggregate. Researchers tested reinforced concrete using various types of FRP. Kissman and Sundar examined reinforced concrete column with one and two layers of glass fiber reinforced polymer (GFRP). Obtained results has been shown that compressive strength and axial strain of reinforced specimens were greater in compare to plain concrete [29]. Sadeghian and Fillmore reinforced concrete specimens with basalt fiber reinforced polymer (BFRP). When reinforcing concrete with two, four and six layers of BFRP, increased strength factor of 1.41, 1.92 and 2.36 was obtained, respectively [30]. Campione et al. has been shown that using BFRP stabilization of post-peak behavior of reinforced concrete could be reached [31]. Aramid fiber reinforced polymer (AFRP), as the confinement of concrete, was studied by Toutanji and Deng [32]. According the authors, dry or wet environment does not have a significant impact on the strength of AFRP reinforced concrete specimens. In 2017, Eid and Paultre proposed the stress-strain model to predict the behavior of concrete reinforced with FRP composites [33].

CFRP still remain a new tendency in the design process. The role of the matrix in the laminate can be played by epoxy resin, and sometimes by the cement matrix [34]. Due to the plasticization of the resin at relatively low temperatures, alternative matrices are being sought for reinforcing concrete structures. In some cases, this role can be played by the cement matrix, which is definitely more resistant to the effects of elevated temperatures. The usage of combining composite materials and inorganic matrices could affect the strengthening of reinforced concrete [35]. The cement matrix is most often made using CEM I 52.5R cement, silica fume, water and a large amount of a new generation superplasticizer (up to $10 \%$ of the cement mass). The effective time for using the cement matrix in FRP laminates is usually no more than $30 \mathrm{~min}$. The major advantages of using cement matrix in lamination process of fiber reinforced materials (FRP) are: high compressive strength (to $100 \mathrm{MPa}$ ), no plastic behavior at high temperatures, low cost, high stiffness and higher resistance to high temperatures with 
epoxy resins. On the other hand, low tensile strength (to $10 \mathrm{MPa}$ ), chemical resistance and bending strength are the major drawbacks.

It has been proven many times that CFRP can protect the structure of concrete [36] and composite structures [37]. However, the use of cement matrix for reinforcing concrete elements in FRP technique depends on many aspects such as concrete strength and FRP type [38]. According to Al-Abdwais, the debonding of FRP reinforcement from the concrete surface could be a crucial failure in the external bond, which could lead to a reduction of the bond strength [39]. It has been shown that flexible and stiff adhesives can be effectively used in strengthening concrete structures with CFRP, where the near-surface mounted (NSM) technique is considered [40,41]. The matrix material in case of FRP composites has crucial functions: to protect the FRP and stresses transfer between FRP and the matrix [42]. Existing studies have demonstrated that bond behavior between CFRP and concrete depends on the type of concrete and the roughness of the concrete surface $[43,44]$.

\section{Research Significance}

In most of the analyzed literature, researchers do not provide detailed information on surface preparation, and often provide basic information that the concrete surface has been cleaned and dusted before the lamination process. Only a few works provide information concerning the method of preparing a concrete surface. In most cases the surface was not prepared using any technological treatment, or was treated using grinding. The lack of morphological characteristics of the concrete surface in many scientific papers inspired the main author of this work to analyze the impact of surface preparation on the efficiency of reinforcing concrete elements with carbon fibers. Due to the plastic behavior of epoxy resins in low temperatures, the authors tried to answer the question of whether a cement matrix could be reasonably used in the lamination process of high-performance concrete. The paper analyzes three types of the most common concrete surfaces: unprepared, sanded and grinded. In summary, the main purpose of the work is to indicate the optimal concrete surface intended for reinforcing when using FRP materials.

\section{Materials and Methods}

\subsection{Preparation of Concrete Mixtures}

The HPSCFR concrete mixture was applied in this research. The materials which were used to create the mixture were as follows: Portland Cement type I $52.5 \mathrm{R}$ with a rapid increase in strength $\left(500 \mathrm{~kg} / \mathrm{m}^{3}\right)$, river sand as fine aggregate $\left(650 \mathrm{~kg} / \mathrm{m}^{3}\right)$, diabase as coarse aggregate $\left(1000 \mathrm{~kg} / \mathrm{m}^{3}\right)$, superplasticizer Sikament FM6 $\left(17.5 \mathrm{~kg} / \mathrm{m}^{3}\right)$, Sika Fume addition as microfiller $\left(60 \mathrm{~kg} / \mathrm{m}^{3}\right)$ and water from waterworks $\left(160 \mathrm{~kg} / \mathrm{m}^{3}\right)$. The water to cement $(\mathrm{w} / \mathrm{c})$ ratio was equal to 0.32 . The steel micro-reinforcement $\left(78 \mathrm{~kg} / \mathrm{m}^{3}\right)$ had the form of steel oar-shape fibers with a length (l) of $30 \mathrm{~mm}$ and an outer diameter (d) of $0.3 \mathrm{~mm}$ (Figure 1a). The tensile strength of the steel fibers, according to the manufacturer (Urban-Metal Sp. $\mathrm{z}$ o.o., Rachowice," Poland), was equal to $1100 \mathrm{MPa}$. The slump flow (SF) test was used to determine the fresh properties of the HPSCFR concrete mixture. The slump flow was equal to $650 \mathrm{~mm}$ (Figure 1b) and the plastic viscosity was $12.5 \mathrm{~s}$, which were defined according to European Standards [45]. Separation of the concrete mixtures' components was not observed. 


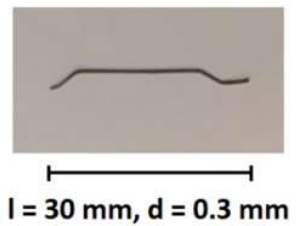

a)

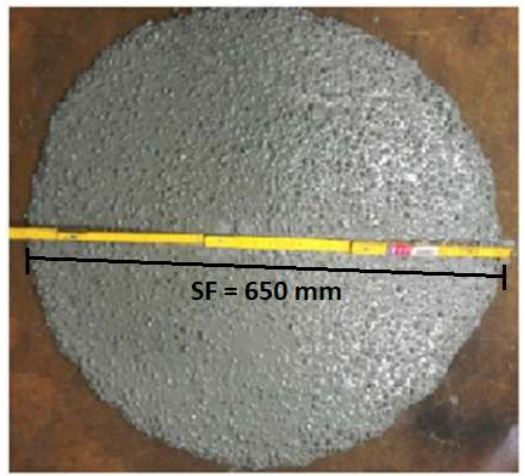

b)

Figure 1. Steel reinforcement (a) and the slump flow test for the concrete mixture (b).

\subsection{Specimens}

A total of 40 specimens were analyzed in the presented studies. All cylinder specimens were $200 \mathrm{~mm}$ in height and had an outer diameter of $100 \mathrm{~mm}$. All columns were divided into three groups: 12 samples were sanded (S) and grinded (G) in each group, and the remaining 12 samples had an unprepared surface (U). The samples were then reinforced with 1, 2 and 3 layers of carbon fibers -4 samples for each series. The samples were marked as follows: U/S/G-1:3-1:4. For example, S-2-4 means a fourth concrete sample with a sanded surface, reinforced with two layers of carbon fibers using cement matrix. Samples S-1, S-2, S-3 and S-4 are the reference samples, and not reinforced in any way.

\subsection{Reinforcing of Concrete with Carbon Fibres}

A carbon fiber (CF) overlap of $50 \mathrm{~mm}$ was provided for each sample. The properties of the CF according to manufacturer are as follow: density $\left(304 \mathrm{~g} / \mathrm{m}^{2}\right)$, effective thickness $(0.167 \mathrm{~mm})$, ultimate elongation at the break (1.7\%), tensile strength (4900 MPa) and Young's modulus (230 GPa). In the case where the samples were reinforced with more than one layer, a pre-cut CF mat was prepared, to ensure the appropriate length of the reinforcement. For samples reinforced with one layer, $364 \mathrm{~mm}$ of CF reinforcement was used. For two and three layers, $678 \mathrm{~mm}$ and $992 \mathrm{~mm}$ were used, respectively. The height of the CF was $200 \mathrm{~mm}$. The specimens were laminated with high performance cement matrix during the dry lay-up process. The content of the cement matrix was as follows (by mass): cement type I 52.5 R: Sika Fume HR: Water: Plasticizier Sikament FM 6, which was equal to 100:30:40:10. The compressive strength of the cement matrix was $64 \mathrm{MPa}$. Firstly, the whole concrete sample was embedded in the cement matrix, and then a CF mat was applied to the concrete surface, which was covered with a cement matrix using a brush, while trying to soak and infiltrate the CF. The thickness of the cement matrix was about $4 \mathrm{~mm}$. The lamination process was carried out at a temperature of $24{ }^{\circ} \mathrm{C}$, and a humidity of $65 \% \pm 5 \%$. The samples reinforced with the cement matrix were tested 28 days after lamination.

\subsection{Instrumentation and Testing Procedure}

The samples were subjected to a uniaxial compression test using a 3000-kN capacity testing machine (Figure 2a, Walter + Bai AG, Löhningen, Switzerland). All the tests were carried out in a local Laboratory of Concrete Structures, in AGH, Cracow, Poland, in a humidity of $50 \pm 5 \%$ and an air temperature of $20 \pm 1^{\circ} \mathrm{C}$. The constant axial force rate, equal to $5 \mathrm{kN}^{*} \mathrm{~s}^{-1}$, was provided during the compression test. The instrumentation and testing procedure were in accordance with norm [46]. The axial displacement, force value and test time were read from a text file. The text file is a record of the test parameters for each sample. This means that the axial displacement values are the displacement values of the testing machine piston during the testing of the elements. The transverse displacements 
were measured using extensometers located at half the height of the samples using four electronic sensors spaced $90^{\circ}$ apart, with an accuracy of $1 \times 10^{-3} \mathrm{~mm}$. The test setup, illustrating the transverse strain gauges applications, is presented in Figure $2 \mathrm{~b}$.

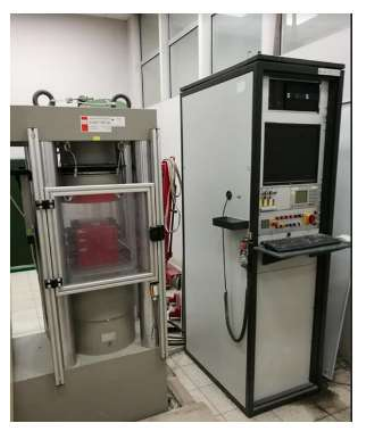

a)

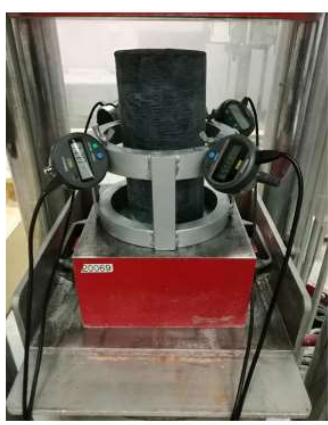

b)

Figure 2. Compressive testing machine Walter + Bai AG (a) and localization of transverse strain gauges (b).

\section{Morphological Characterization of a Concrete Surface}

\subsection{Laser Scanner}

The characteristics of the concrete surfaces were determined by scanning the surface. Concrete surface scanning was performed using an innovative 3D laser scanner (Wrocław University of Science and Technology, Wrocław, Poland) based on the method of laser triangulation, which involved measuring the deformation of the line produced by the laser beam. The distances between individual points located on the tested surface were measured with a stepper motor-driven camera, thanks to which, measurements can be made with an accuracy of $15 \mu \mathrm{m}$ in profiles spaced $10 \mathrm{~mm}$ apart. The laser has a compact structure, and therefore tests can be carried out in both laboratory and field conditions. The device assigns three coordinates to each measuring point, describing its location on the test surface. The measurement data file is saved in asc format. The result of the scan is a virtual 3D image of the morphology of the surface being examined. The image was analyzed in order to obtain the values of the parameters that describe the surface morphology [47].

\subsection{Description of the Concrete Surface}

The profile material share curve is the curve that illustrates the profile material share at a certain level c (most often expressed as a percentage) as a function of distance c from the line passing through the highest point of the profile, and which is parallel to the average line. This curve is also called the Abbott-Firestone curve [48-51]. Thanks to the shape of the curve of the material share of the profile, it is possible to analyze the surface resistance of a given material to tribological wear. The shape of the material share curve is determined using parameters determined on its basis [24]. The following areas can be distinguished in the material share curve area:

- $\quad$ Profile elevation zone;

- $\quad$ Profile core zone;

- $\quad$ Profile recess zone.

The following parameters of the material share curve of the surface roughness profile are distinguished (Figure 3):

- Average height of high mid elevations above the core of the roughness profile-reduced height of $\mathrm{R}_{\mathrm{pk}}$;

- The depth of the middle part of the profile, determined by a simple linearizing material share curve-depth of the roughness core $\mathrm{R}_{\mathrm{k}}$; 
- Average depth of deep pits under the roughness core-reduced depth of $\mathrm{R}_{\mathrm{vk}}$ pits.

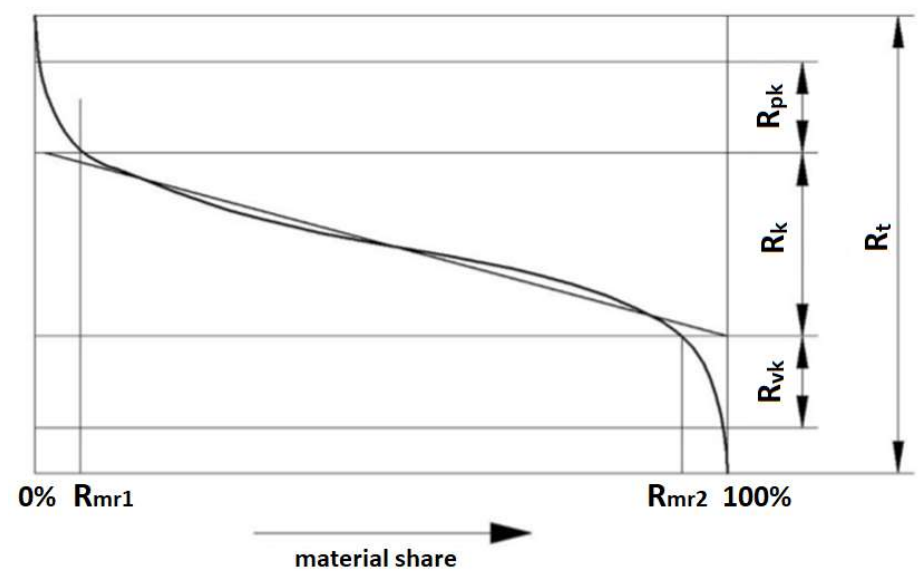

Figure 3. Rough material profile curve and its parameters.

The material fraction $R_{\mathrm{mr} 1}$ corresponds to the upper limit of the core of the profile, while the material fraction $R_{m r 2}$ corresponds to the lower limit of the core. The $R_{t}$ is the distance between the highest and the lowest point on the surface roughness profile.

\subsection{Preparation of the Specimens}

In order to characterize the surface of the concrete, an additional three cubic samples of HPSCFRC with dimensions equal to $10 \mathrm{~cm} \times 10 \mathrm{~cm} \times 10 \mathrm{~cm}$ were made. The first sample had an unprepared surface (sample U1-Figure 4a). The second cube was grinded (sample G1-Figure 4b) and the third one was sanded (sample S1-Figure 4c) in the same manner as the cylinder specimens. The grinded surface was prepared using a ceramic grinding disc (Figure 5a), while the sanded surface was made using a siphon sander with a water nozzle (Figure $5 b$ ).

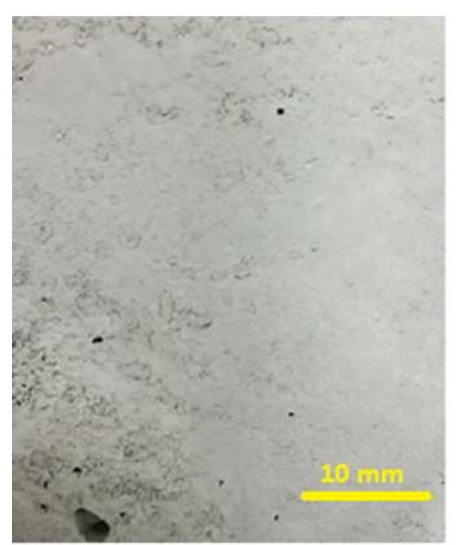

a)

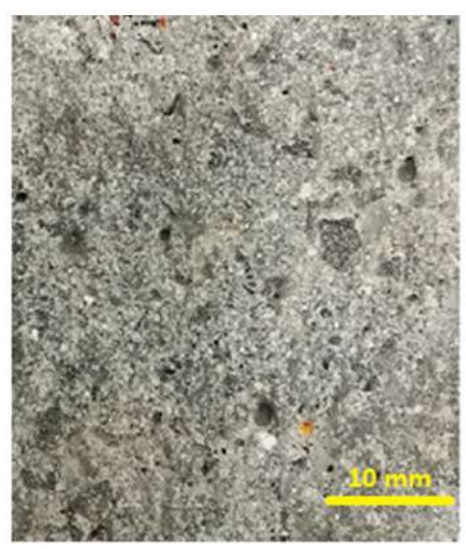

b)

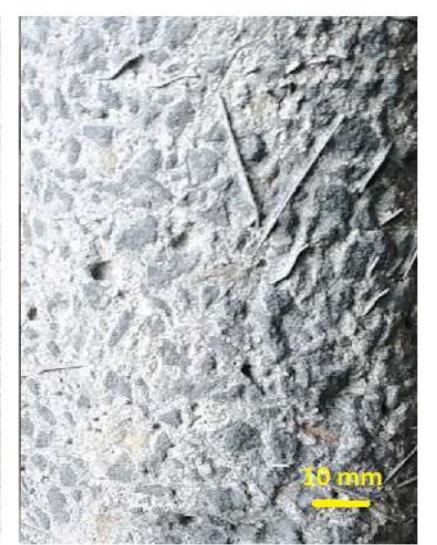

c)

Figure 4. Unprepared surface (a), grinded surface (b) and sanded surface (c). 


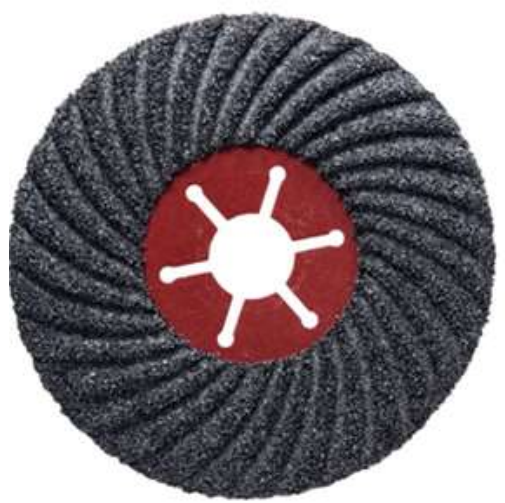

a)

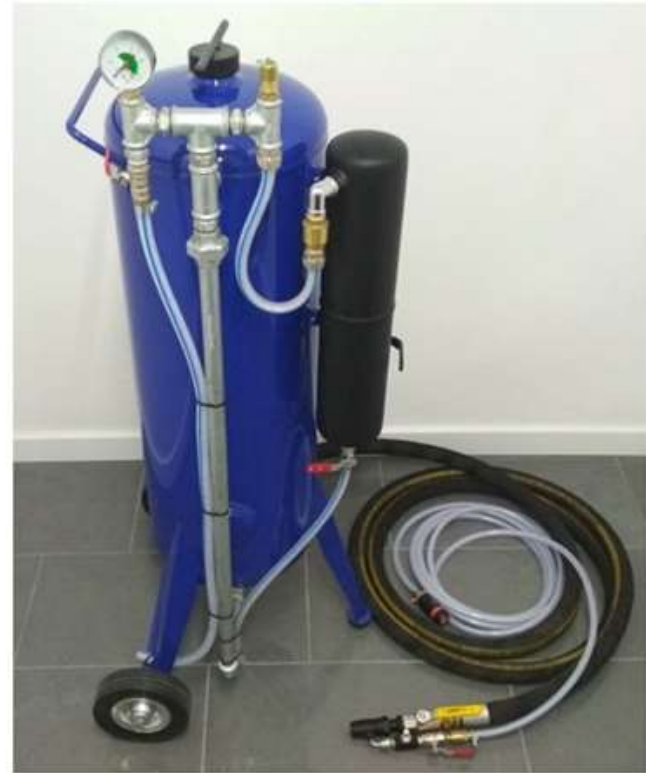

b)

Figure 5. Ceramic grinding disc (a) and siphon blasting machine with a water nozzle (b).

\subsection{Results}

The Abbott-Firestone curve for the unprepared, sanded and grinded concrete surfaces is presented in Figure 6. When analyzing the obtained values, it can be stated that the material proportions corresponding to the upper $\left(\mathrm{R}_{\mathrm{mr} 1}\right)$ and lower $\left(\mathrm{R}_{\mathrm{mr} 2}\right)$ core boundaries are similar for the unprepared and grinded surfaces. In the case of the sanded surface, it should be noted that the material proportion corresponding to the upper limit of the core is more than half, and the lower limit of the core has the lowest value with regards to the other two surfaces. The roughness core depth $R_{k}$ is the most important parameter that says a lot about the nature of the surface. When analyzing the samples macroscopically, it could be clearly stated that the unprepared surface has the smallest roughness, followed by the grinded surface, with the sanded surface having the largest roughness. Scanning studies confirmed this fact by providing Figure $7 \mathrm{a}-\mathrm{c}$.

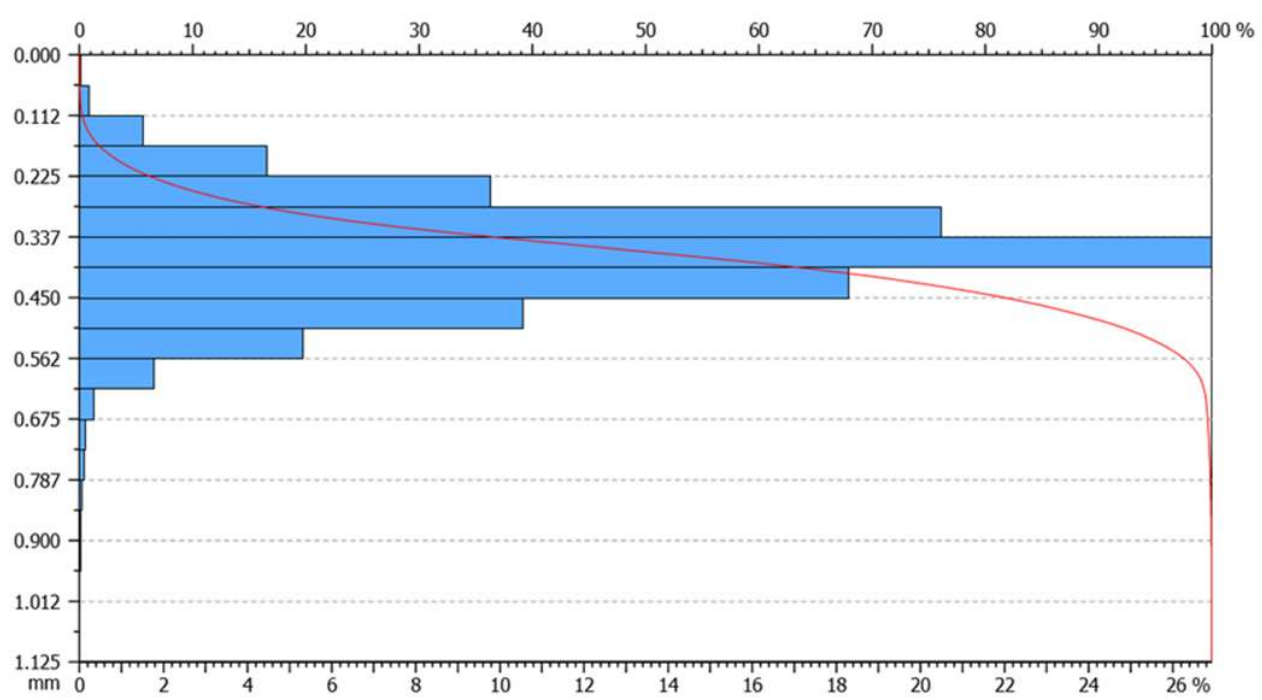

(a)

Figure 6. Cont. 


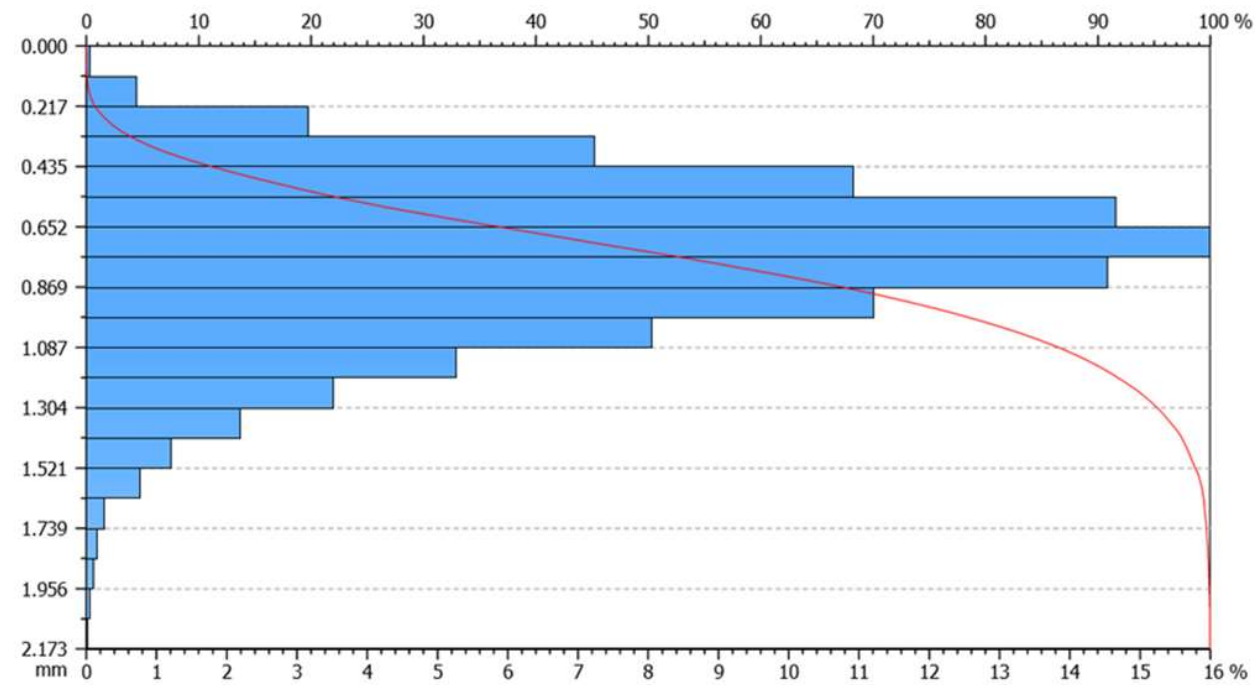

(b)

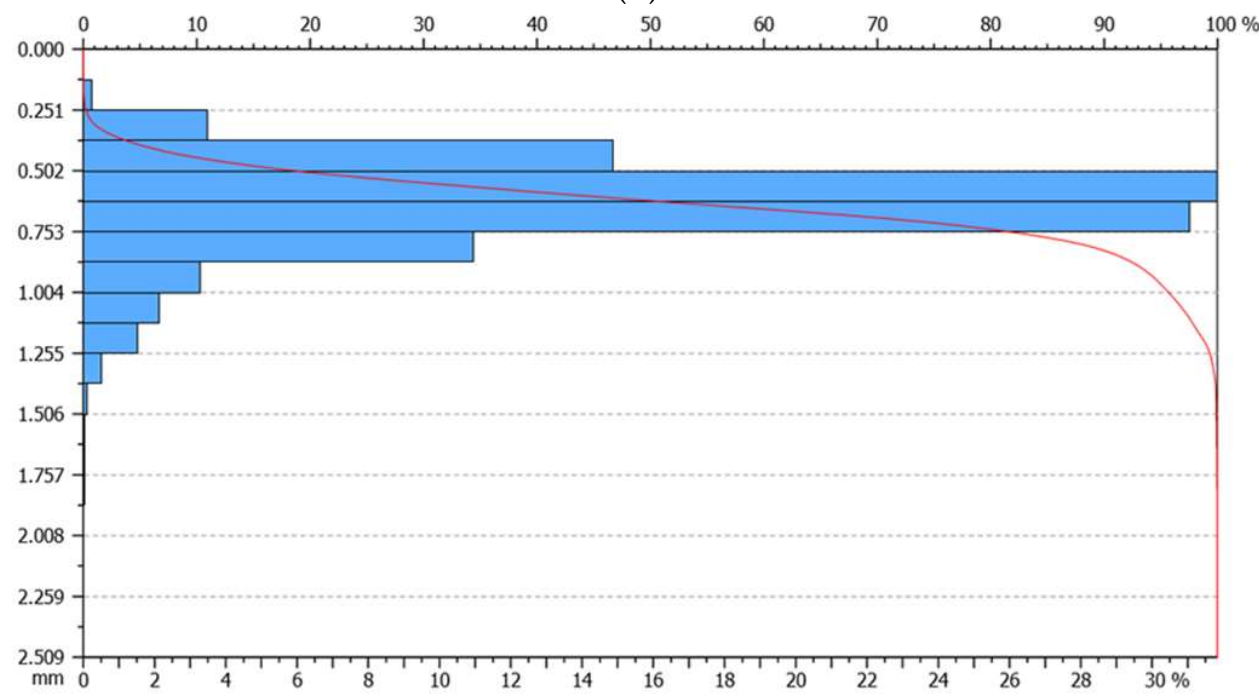

(c)

Figure 6. Abbott-Firestone curve for concrete surfaces: unprepared (a), sanded (b) and grinded (c).

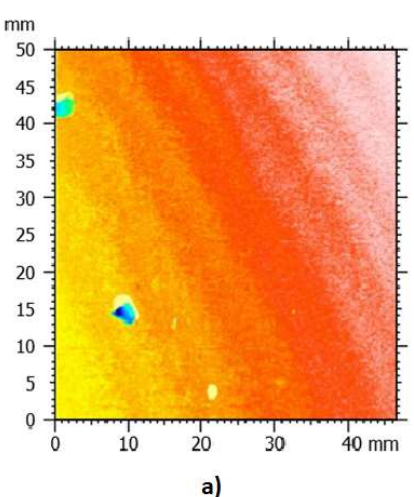

a)

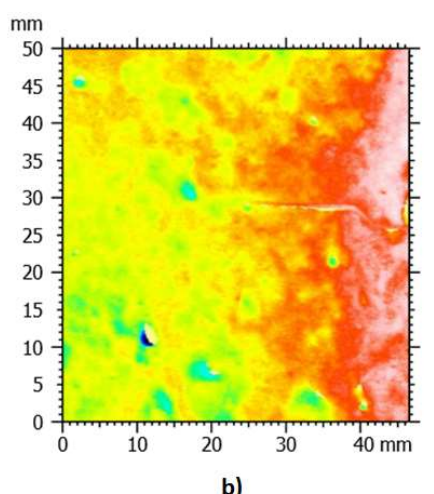

b)

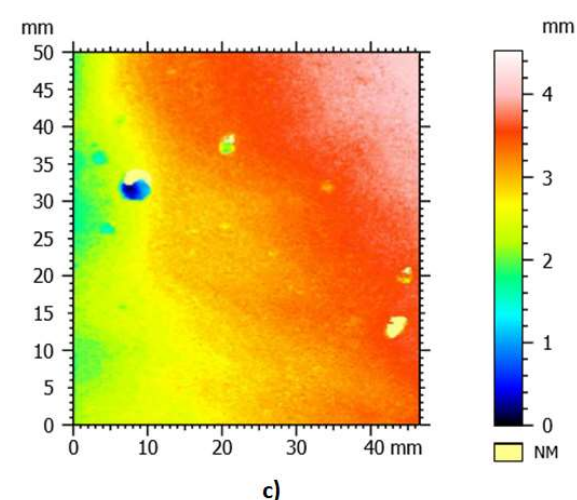

c)

Figure 7. Surface image of samples after scanning with a laser scanner: unprepared (a), sanded (b) and grinded (c).

The depth of the middle part of the profile was the smallest for the unprepared surface, and was, on average, $0.21 \mathrm{~mm}$, whereas, for the sanded and grinded surface, it was $0.6935 \mathrm{~mm}$ and $0.3556 \mathrm{~mm}$, respectively. The average depth of deep cavities under the roughness profile core was the greatest 
for the sanded surface $(0.3884 \mathrm{~mm})$, decreasing for the grinded surface $(0.3427 \mathrm{~mm})$ and reaching the lowest value for the unprepared surface $(0.1142 \mathrm{~mm})$. The average height of high mid elevations above the core of the roughness profile was $0.09805 \mathrm{~mm}, 0.166 \mathrm{~mm}$ and $0.1228 \mathrm{~mm}$ for the unprepared, sanded and grinded surfaces, respectively. In summary, it can be stated that the highest roughness was found in the sanded surface, and the smallest in the case of the unprepared surface. The grinded surface in this respect is in between the other two. The roughness profile parameters are presented in Table 1.

Table 1. Roughness profile parameters.

\begin{tabular}{cccc}
\hline Parameter & Surface U & Surface S & Surface G \\
\hline $\mathrm{R}_{\mathrm{k}}[\mathrm{mm}]$ & 0.21 & 0.6935 & 0.3556 \\
$\mathrm{R}_{\mathrm{pk}}[\mathrm{mm}]$ & 0.09805 & 0.166 & 0.1282 \\
$\mathrm{R}_{\mathrm{vk}}[\mathrm{mm}]$ & 0.1142 & 0.3884 & 0.3427 \\
$\mathrm{R}_{\mathrm{mr} 1}[\%]$ & 11.48 & 8.079 & 9.953 \\
$\mathrm{R}_{\mathrm{mr} 2}[\%]$ & 86.17 & 86.71 & 87.74 \\
\hline
\end{tabular}

\section{Results}

Detailed results for the samples reinforced with cement matrix are presented in Table 2. In turn, Table 3 presents the average values of the results that were obtained for the HPSCRFC and the group of reinforced samples. The stress-strain characteristics for all samples are presented in Figure 8. For the concrete reinforced with one layer of CFRP, a slight increase in strength was observed, which depended on the type of concrete surface. The average compressive strength was equal to $82.94 \mathrm{MPa}, 83.87 \mathrm{MPa}$ and $84.91 \mathrm{MPa}$ for the concretes with an unprepared, sanded and grinded surface, respectively. The average axial deformability of the samples at the moment of obtaining the maximum load capacity was in this case equal to $0.0066,0.0070$ and 0.0072 for the concretes with an unprepared, sanded and grinded surface, respectively. The average lateral deformability of the samples at the same time of failure was $0.0027,0.0028$ and 0.0029 , respectively. When analyzing these data, it can be concluded that there is no significant difference between the obtained values of strength and deformability of concrete, with regards to the type of surface preparation. These values differ slightly, and therefore, it can be assumed that the differences are within a statistical error of $5 \%$.

In the case of samples reinforced with two layers of CFRP, a slight increase in compressive strength was observed, and it amounted to $88.69 \mathrm{MPa}, 83.67 \mathrm{MPa}$ and $94.79 \mathrm{MPa}$ for the unprepared, sanded and grinded samples, respectively. This means that there is an increase in strength, when compared to non-reinforced concrete, by $10 \%, 4 \%$ and $18 \%$, respectively. The standard deviation of the compressive strength was the lowest for the samples with a sanded surface and amounted to $1.95 \mathrm{MPa}$. It was higher for the grinded surface (11.89 MPa)-and the unprepared surface (5.44 MPa). The axial deformability of the samples at the moment of the failure of the specimens was equal to $0.0081,0.0080$ and 0.0088 for the concrete with the unprepared, sanded and grinded surface, respectively. The average lateral deformability of the samples was $0.0033,0.0033$ and 0.0038 , respectively. For the samples with the grinded concrete surface, the obtained average axial deformation was higher by $9 \%$ and $10 \%$ when compared to the samples with the unprepared and sanded surfaces. The average transverse deformation was also higher-a $15 \%$ increase was recorded for the concrete with a grinded surface, when compared to the samples with the unprepared and sanded surfaces.

For the samples reinforced with three layers of CFRP, a variable value of compressive strength was also found for the samples with the unprepared, sanded and grinded surfaces, and it amounted to 86.34 MPa, 81.82 MPa and $95.57 \mathrm{MPa}$, respectively. This means that there is an increase in strength when compared to non-reinforced concrete by $7 \%, 2 \%$ and $19 \%$, respectively. The standard deviation of the compressive strength was greatest for the samples with the grinded surface. There was also no change in the average value of the compressive strength of the samples with the sanded surface. The average axial deformability of the samples at the time of failure was equal to $0.0091,0.0084$ and 
0.0098 for the concrete with the unprepared, sanded and grinded surfaces, respectively. The lateral deformability of the samples was equal to $0.0036,0.0035$ and 0.0041 , respectively. For the grinded surface, the average axial deformability was by $8 \%$ and $17 \%$ higher than for the samples with the unprepared and sanded surfaces. The average transverse strains were also higher-a $14 \%$ and $17 \%$ increase for the concrete with the grinded surface was noted, when compared to the samples with the unprepared and sanded surfaces.

Table 2. Detailed results for the samples reinforced with cement matrix.

\begin{tabular}{|c|c|c|c|}
\hline Specimen & Maximum Compressive Stress [MPa] & Axial Strain During Fracture [-] & Transverse Strain During Fracture [-] \\
\hline S-1 & 82.35 & 0.00604 & 0.00227 \\
\hline S-2 & 81.43 & 0.00630 & 0.00236 \\
\hline S-3 & 78.55 & 0.00604 & 0.00220 \\
\hline S-4 & 79.05 & 0.00633 & 0.00244 \\
\hline U-1-1 & 77.63 & 0.00638 & 0.00276 \\
\hline $\mathrm{U}-1-2$ & 81.32 & 0.00634 & 0.00263 \\
\hline U-1-3 & 92.64 & 0.00665 & 0.00270 \\
\hline U-1-4 & 80.16 & 0.00716 & 0.00282 \\
\hline U-2-1 & 90.25 & 0.00806 & 0.00331 \\
\hline U-2-2 & 82.63 & 0.00829 & 0.00350 \\
\hline U-2-3 & 95.38 & 0.00818 & 0.00321 \\
\hline $\mathrm{U}-2-4$ & 86.48 & 0.00776 & 0.00321 \\
\hline U-3-1 & 85.42 & 0.00954 & 0.00384 \\
\hline $\mathrm{U}-3-2$ & 83.46 & 0.00949 & 0.00380 \\
\hline U-3-3 & 82.25 & 0.00816 & 0.00338 \\
\hline $\mathrm{U}-3-4$ & 94.24 & 0.00919 & 0.00356 \\
\hline S-1-1 & 78.20 & 0.00672 & 0.00290 \\
\hline S-1-2 & 84.63 & 0.00681 & 0.00261 \\
\hline S-1-3 & 90.01 & 0.00790 & 0.00290 \\
\hline S-1-4 & 82.65 & 0.00661 & 0.00294 \\
\hline S-2-1 & 83.99 & 0.00792 & 0.00332 \\
\hline S-2-2 & 84.58 & 0.00811 & 0.00324 \\
\hline S-2-3 & 80.85 & 0.00837 & 0.00360 \\
\hline S-2-4 & 85.81 & 0.00816 & 0.00310 \\
\hline S-3-1 & 83.25 & 0.00758 & 0.00303 \\
\hline S-3-2 & 89.99 & 0.0109 & 0.00447 \\
\hline S-3-3 & 78.58 & 0.00755 & 0.00332 \\
\hline S-3-4 & 75.97 & 0.00798 & 0.00337 \\
\hline G-1-1 & 90.37 & 0.00770 & 0.00300 \\
\hline G-1-2 & 80.80 & 0.00574 & 0.00215 \\
\hline G-1-3 & 85.80 & 0.00829 & 0.00332 \\
\hline G-1-4 & 82.66 & 0.00710 & 0.00303 \\
\hline G-2-1 & 103.89 & 0.00969 & 0.00410 \\
\hline G-2-2 & 88.38 & 0.00745 & 0.00306 \\
\hline G-2-3 & 81.26 & 0.00738 & 0.00319 \\
\hline G-2-4 & 105.61 & 0.01079 & 0.00478 \\
\hline G-3-1 & 102.47 & 0.00879 & 0.00343 \\
\hline G-3-2 & 88.88 & 0.01155 & 0.00462 \\
\hline G-3-3 & 85.32 & 0.00803 & 0.00353 \\
\hline G-3-4 & 105.60 & 0.01067 & 0.00480 \\
\hline
\end{tabular}

Table 3. Average values of the obtained results for the high-performance, self-compacting, fiber-reinforced concrete (HPSCFRC) and samples reinforced with cement matrix.

\begin{tabular}{|c|c|c|c|c|c|c|}
\hline Matrix & $\begin{array}{c}\text { Type of Concrete } \\
\text { Surface }\end{array}$ & $\begin{array}{c}\text { Number of CFRP } \\
\text { Layers }\end{array}$ & $\begin{array}{c}\text { Average } \\
\text { Compressive } \\
\text { Strength [MPa] }\end{array}$ & $\begin{array}{l}\text { Standard Deviation } \\
\text { of Compressive } \\
\text { Strength [MPa] }\end{array}$ & $\begin{array}{c}\text { Average Axial } \\
\text { Strain during } \\
\text { Fracture [-] }\end{array}$ & $\begin{array}{c}\text { Average Transverse } \\
\text { Strain during } \\
\text { Fracture [-] }\end{array}$ \\
\hline $\begin{array}{l}\text { Unreinforced } \\
\text { specimens }\end{array}$ & $\mathrm{U}$ & 0 & 80.35 & 1.83 & 0.0062 & 0.0023 \\
\hline \multirow{3}{*}{$\begin{array}{c}\text { Cement } \\
\text { matrix }\end{array}$} & $\mathrm{U}$ & $\begin{array}{l}1 \\
2 \\
3\end{array}$ & $\begin{array}{l}82.94 \\
88.69 \\
86.34\end{array}$ & $\begin{array}{l}6.65 \\
5.44 \\
5.42\end{array}$ & $\begin{array}{l}0.0066 \\
0.0081 \\
0.0091\end{array}$ & $\begin{array}{l}0.0027 \\
0.0033 \\
0.0036\end{array}$ \\
\hline & S & $\begin{array}{l}1 \\
2 \\
3 \\
\end{array}$ & $\begin{array}{l}83.87 \\
83.67 \\
81.82\end{array}$ & $\begin{array}{l}4.90 \\
1.95 \\
6.25\end{array}$ & $\begin{array}{l}0.0070 \\
0.0080 \\
0.0084\end{array}$ & $\begin{array}{l}0.0028 \\
0.0033 \\
0.0035\end{array}$ \\
\hline & G & $\begin{array}{l}1 \\
2 \\
3\end{array}$ & $\begin{array}{l}84.91 \\
94.79 \\
95.57\end{array}$ & $\begin{array}{c}4.19 \\
11.89 \\
9.97\end{array}$ & $\begin{array}{l}0.0072 \\
0.0088 \\
0.0098\end{array}$ & $\begin{array}{l}0.0029 \\
0.0038 \\
0.0041\end{array}$ \\
\hline
\end{tabular}




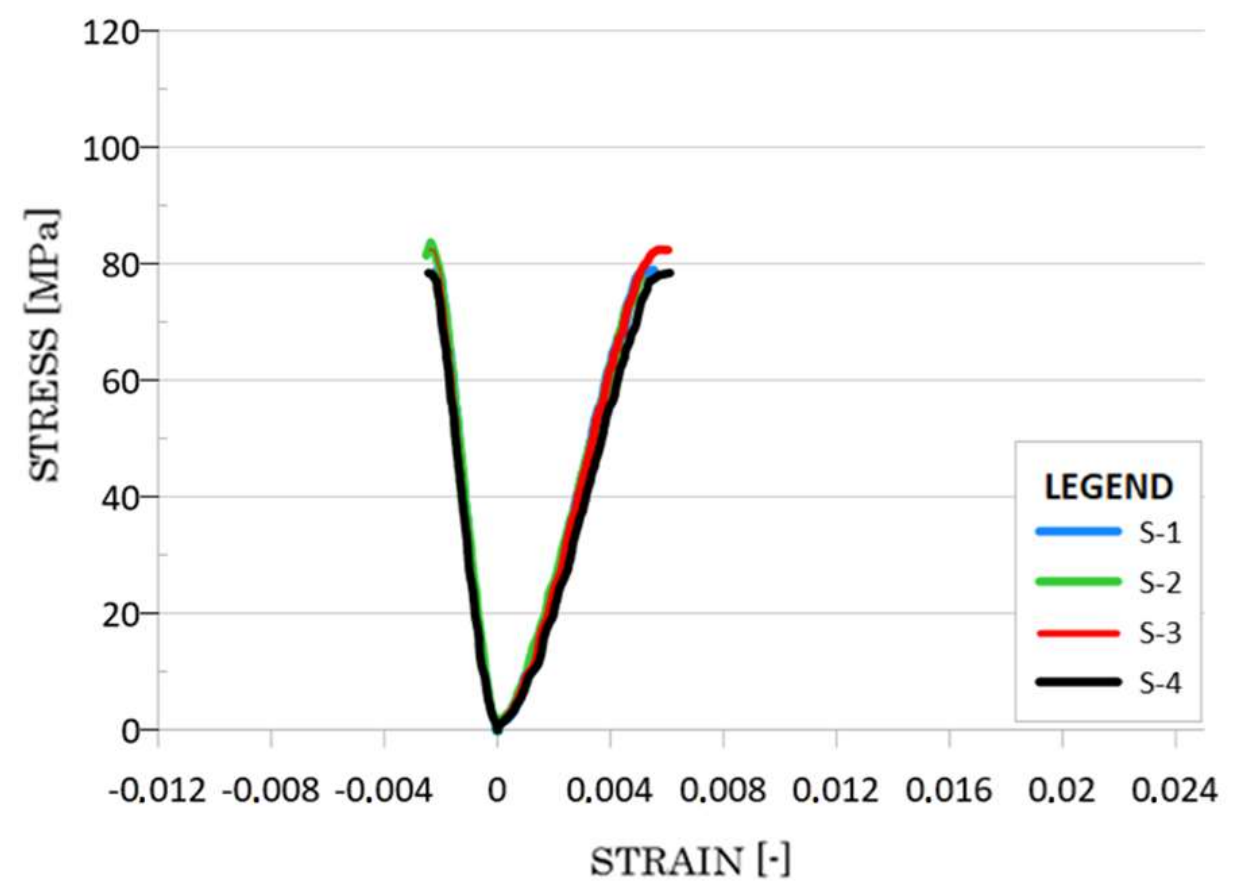

(a)

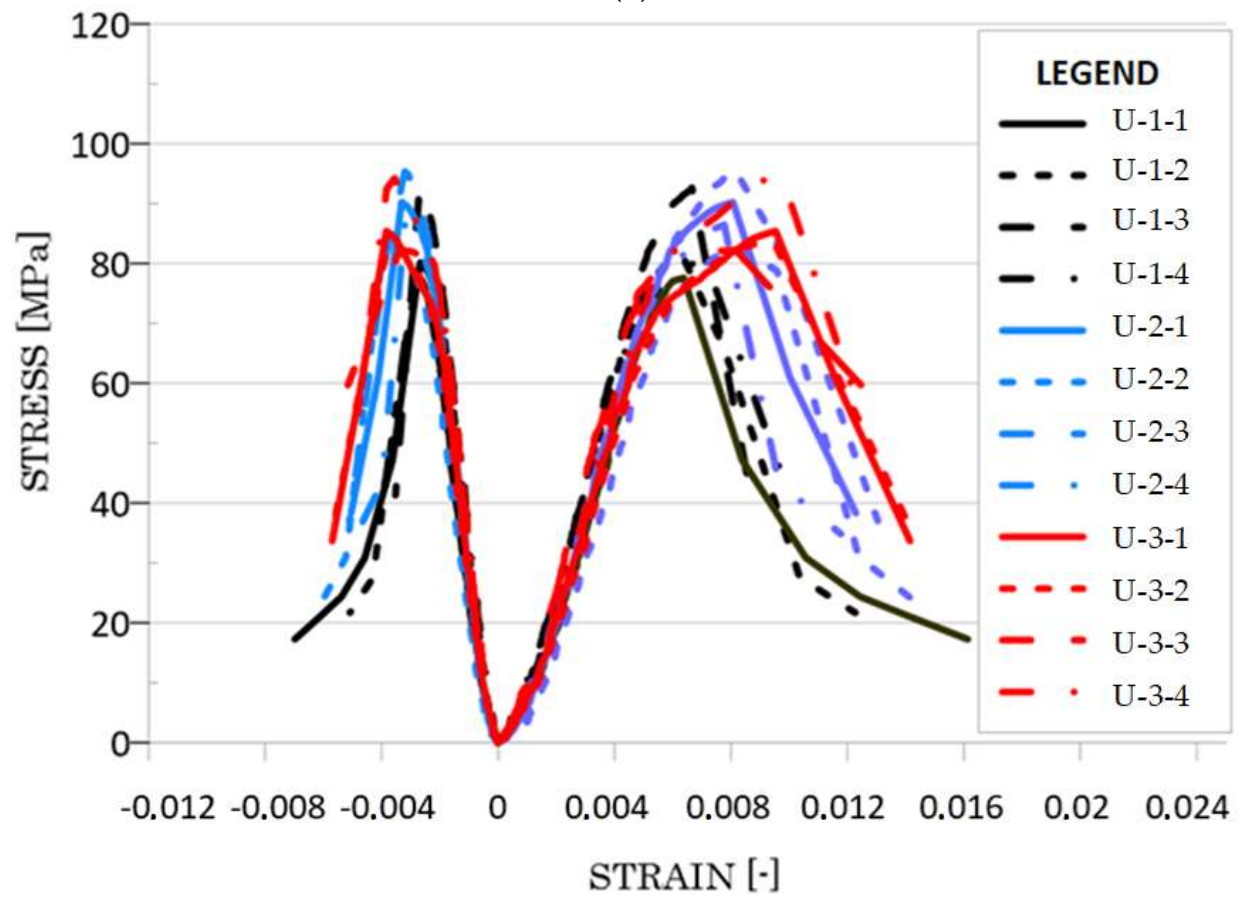

(b)

Figure 8. Cont. 


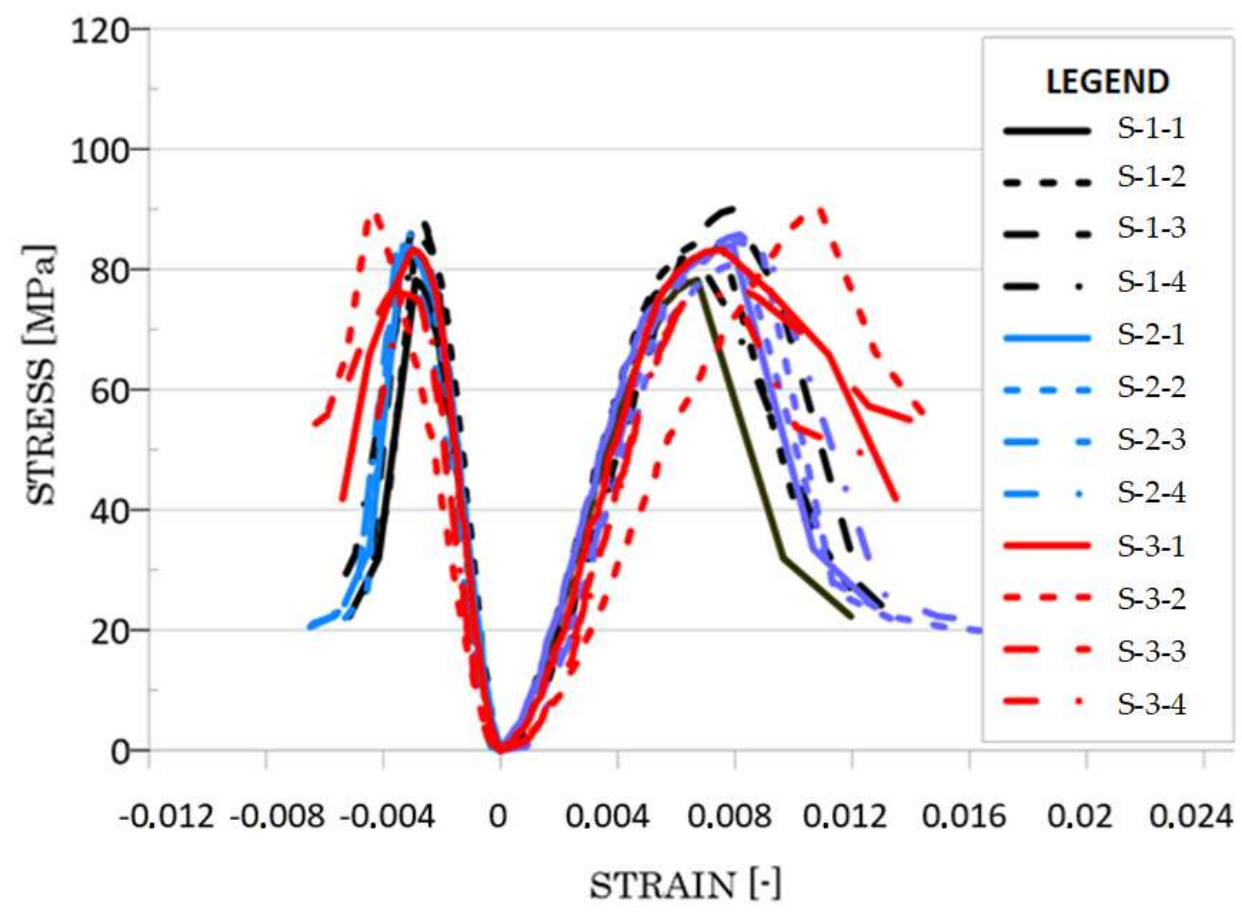

(c)

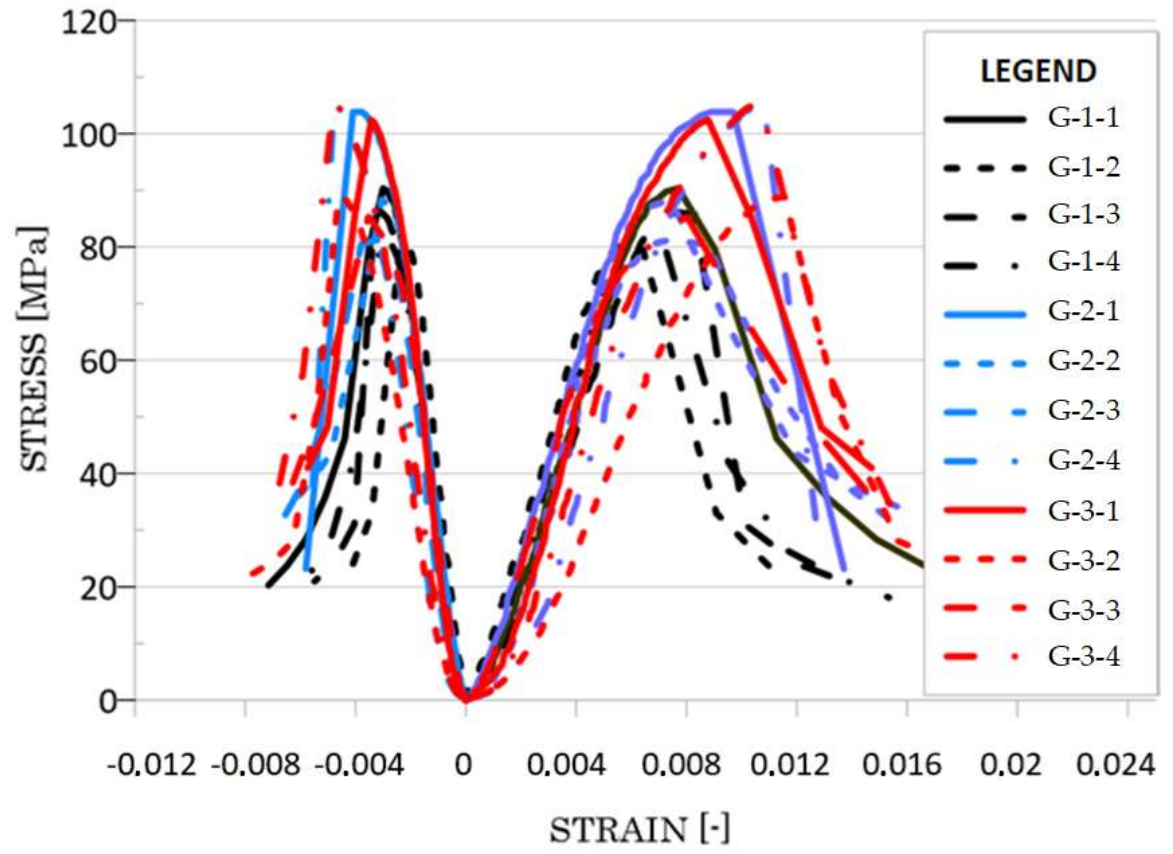

(d)

Figure 8. Stress-strain characteristics for: HPSCFRC (a); HPSCFRC reinforced carbon fibre reinforced polymer (CFRP) with an unprepared concrete surface (b); HPSCFRC reinforced CFRP with a sanded concrete surface (c); HPSCFRC reinforced CFRP with grinded concrete surface (d).

\subsection{The Course of Failure}

A macroscopic analysis of the failure of the samples reinforced with one layer of carbon fibers is presented below. In the case of CFRP layers in the amount of more than one, the damage had a similar course, and the adhesion between the first layer of reinforcement and the concrete surface is crucial for the failure process. In all the cases, the overlap was cut. All the samples after the tests are presented in Figure 9. 


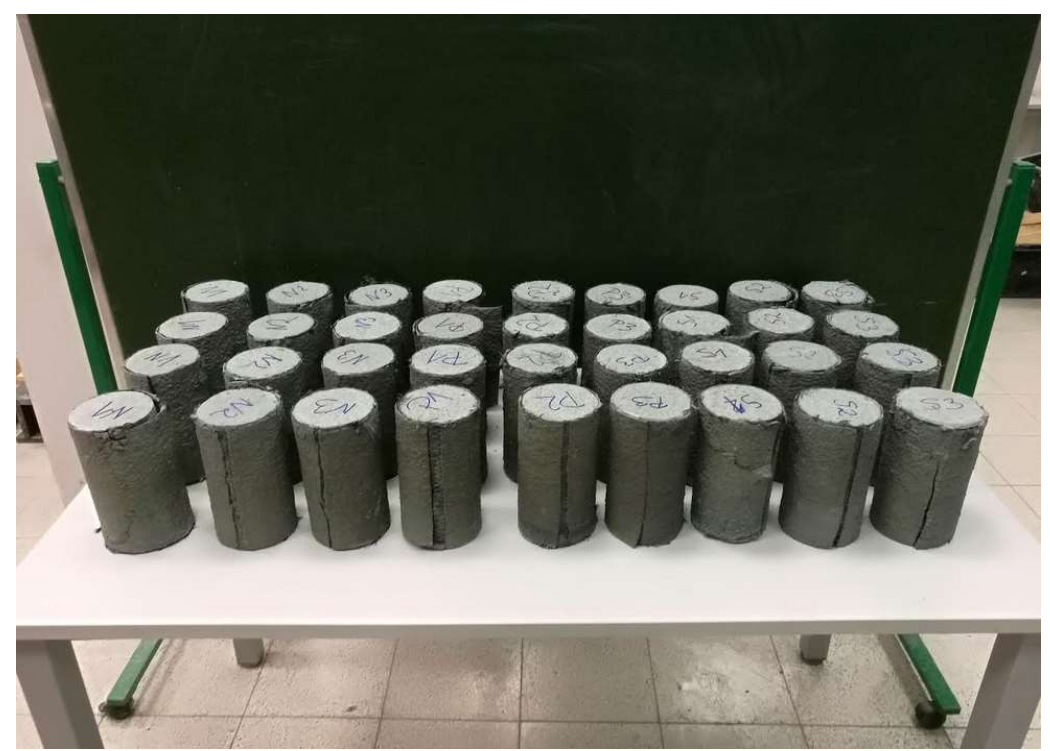

Figure 9. Concrete samples reinforced with carbon fibers using a cement matrix-state after the failure tests.

\subsection{Unprepared Surface}

In the case of the samples with the unprepared surface, it should be noted that the adhesion of carbon fibers to a high-performance cement matrix is similar to the adhesion of this matrix to the concrete surface. Figure 10 shows the cement matrix, which is detached from the concrete surface (red area), adhering to the carbon fibers in a certain area. The yellow area indicates that the adhesion between the cement matrix and the concrete surface was relatively good. On the surface of the matrix, groups of carbon fibers that are glued to it could be observed locally. This may indicate a local and better infiltration of the carbon fibers with the cement matrix.

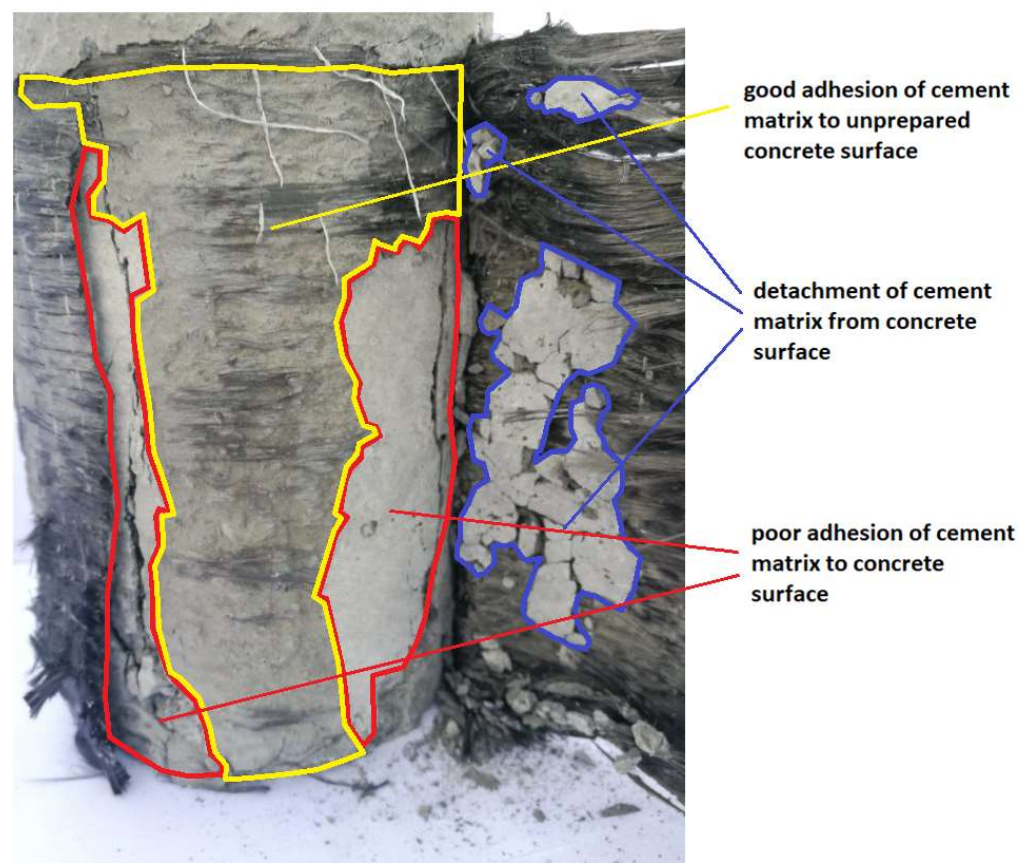

Figure 10. Analysis of the failure of the connection between the carbon fiber reinforced with the cement matrix and the unprepared concrete surface. 


\subsection{Sanded Surface}

The better adhesion of the cement matrix to the concrete surface can be observed in the case of the sanded surface. Only a negligible part of the cement matrix remained glued to the carbon fibers-some of them remained on the high-performance matrix during the failure (Figure 11). Locally, places of low adhesion of the matrix to the concrete surface were observed-this could be due to the local pressure of the laminate surface in the place of a larger depression in the surface, which could cause displacement of the fresh mixture, due to its squeezing.

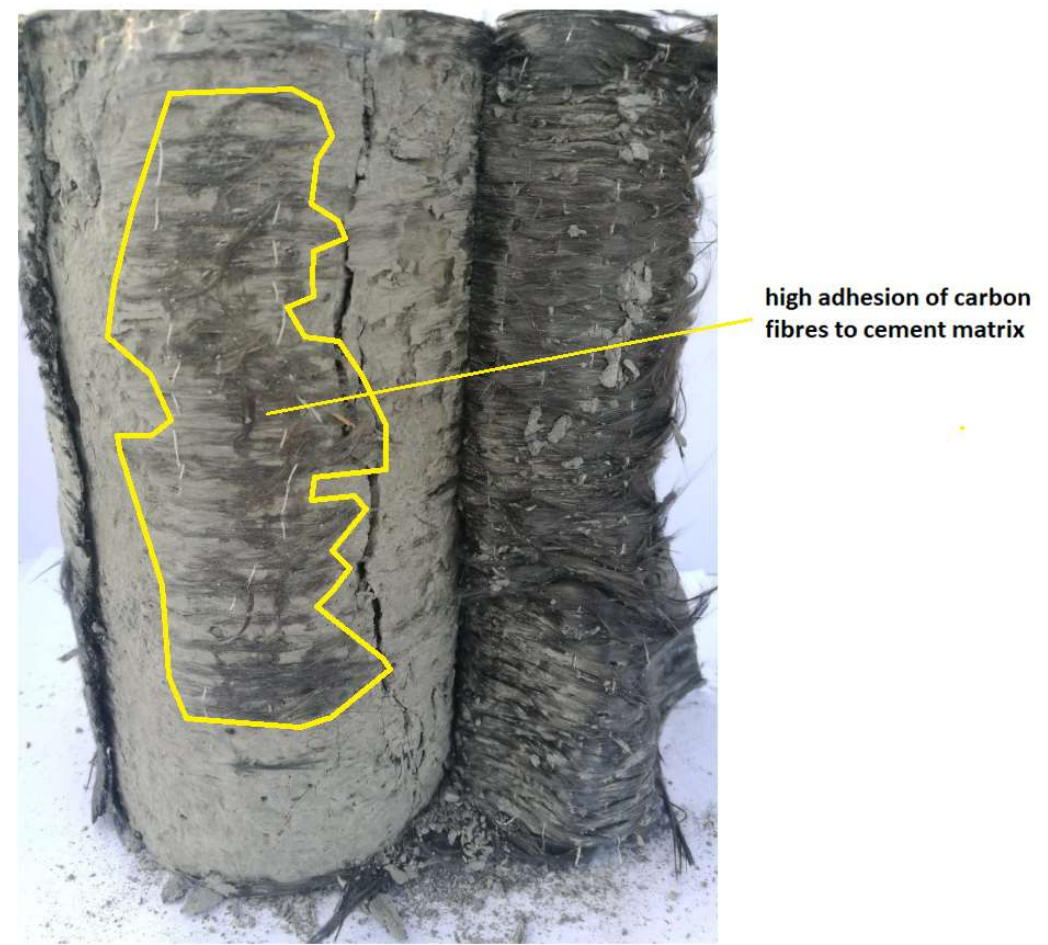

(a)

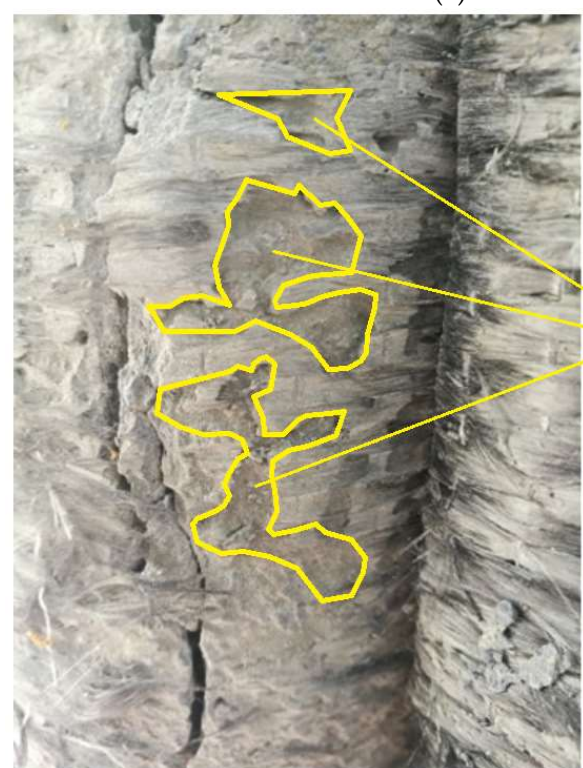

lack of cooperation

between carbon fibres

and concrete substrate

(b)

Figure 11. Analysis of the failure of the connection between the carbon fiber reinforced with the cement matrix and the sanded concrete surface: view of the entire sample (a) and enlargement of the extrusion area of the cement matrix $(\mathbf{b})$. 


\subsection{Grinded Surface}

In the case of the grinded surface, similar phenomena were observed as for the unprepared surface, with the proviso that in this case these phenomena were more dispersed and did not occur on large surfaces. Figure 12 shows the numerous and small areas where the adhesion stresses between the carbon fibers and the cement matrix are greater than between the cement matrix and the concrete surface, and also these areas where the adhesion between the cement matrix and the concrete surface is greater than between the carbon fibers and the cement matrix. A better infiltration of carbon fibers with the cement matrix than in other cases is characteristic for this surface. This may affect the fact that the greatest strengthening efficiency was demonstrated for just the grinded surface.

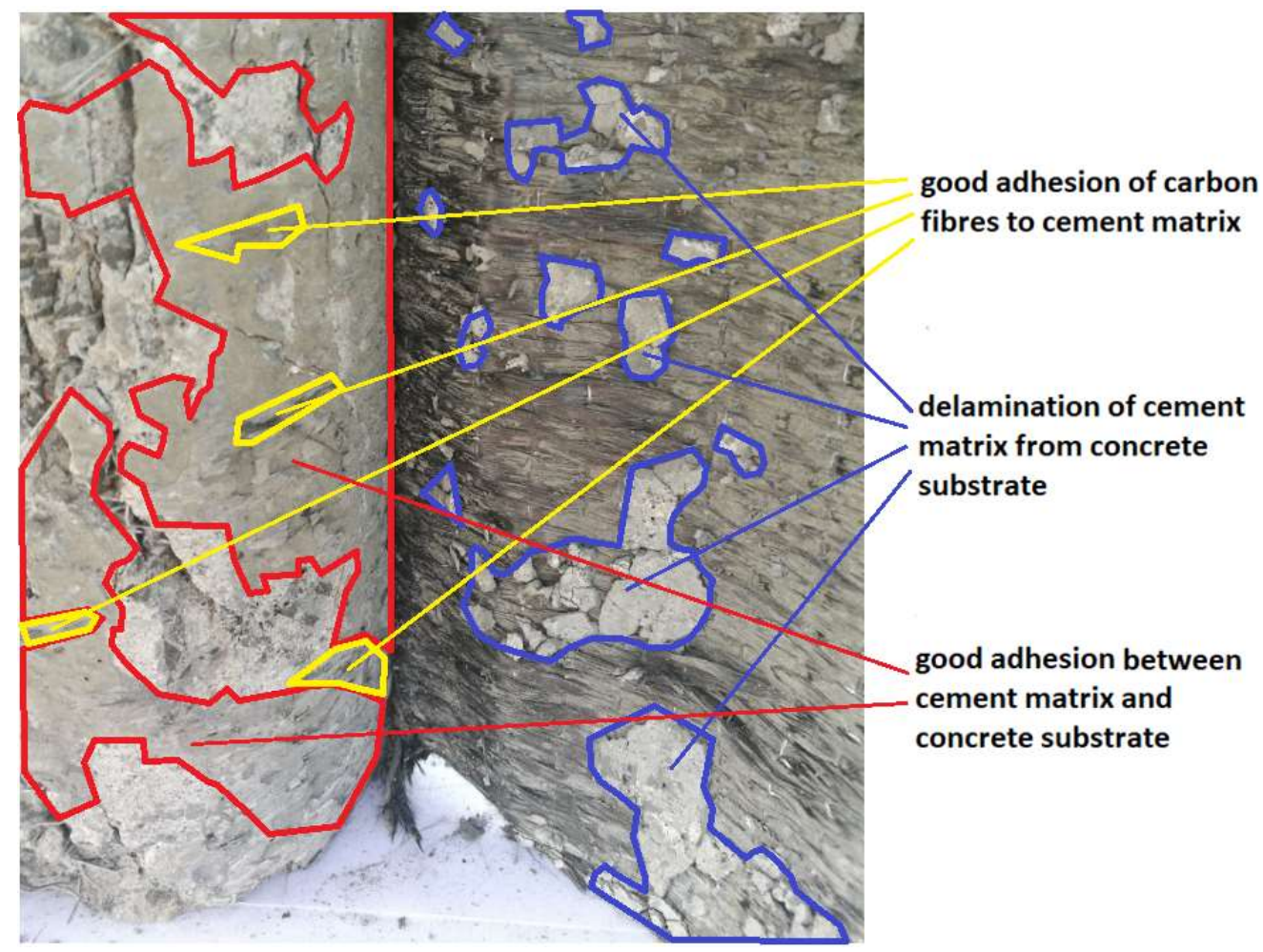

Figure 12. Analysis of the failure of the connection between the carbon fibers reinforced with the cement matrix and the grinded concrete surface.

To sum up, the best cooperation of external reinforcement with a concrete core was demonstrated for the grinded concrete surface. The surface of high-performance concrete is a specific surface, which is due, among other reasons, to its high tightness and low open porosity. Hence, low cement adhesion to the unprepared surface may occur. In the process of strengthening the samples using the considered method, their surface, after the application of the reinforcement, was subjected to some pressure in order to achieve a better infiltration of the fibers. This pressure was made manually by the same person for all the samples. In the case of the sanded surface, it was possible to locally squeeze the fresh cement matrix from the deeper troughs of this surface, which after unloading resulted in the creation of an empty space between the carbon fiber mats and the deeper part of the surface, possible affecting the results. The grinded surface, which has a higher roughness than the unprepared surface, and a smaller roughness than the sanded surface, could have been subjected to the best combination of all the surface types considered, which was confirmed by the results of the compressive strength of the samples.

\section{Conclusions}

The best cooperation of external CF reinforcement with a concrete core was obtained for the grinded concrete surface. The surface of HPSCFRC is a specific surface, due to, among other reasons, 
its high tightness and low open porosity, when compared to normal performance concrete. Therefore, there could be a low cement mortar adhesion to the unprepared surface. In general, the strength of concrete increases as the number of reinforcing layers increases. However, this regularity was only obtained for the grinded concrete surface. Surface roughness and its morphology significantly affect the obtained results. The lack of preparation of the concrete surface before lamination or too big differences in the height of the surface profile (as in the case of the sanded surface) leads to low cooperation between carbon fibers and the HPSCFRC surface. The most optimal preparation process of concrete substrate is grinding. Given the high cost of CF reinforcement, it is not recommended to use cement matrix, due to low strengthening efficiency, when reinforcing high-strength concrete.

Author Contributions: K.A.O. and R.K. conceived and designed the experiments; K.A.O. and P.D. performed the experiments; K.A.O., R.K. and P.D. analyzed the data; K.A.O. wrote the paper (original and revised draft). All authors have read and agreed to the published version of the manuscript.

Funding: This research was funded by the Faculty of Civil Engineering at the Institute of Building Materials and Structures.

Acknowledgments: The author would like to thank Marek Kawalec from Sika Poland for his technical support in the field of composite materials. I would also like to thank Agnieszka Chowaniec from Wroclaw University of Technology for scanning the concrete surfaces.

Conflicts of Interest: The authors declare no conflict of interest.

\section{References}

1. Yang, W.; Gang, W.; Guofen, L. Performance of circular concrete-filled fiber-reinforced polymer-steel composite tube columns under axial compression. J. Reinf. Plast. Compos. 2014, 33, 1911-1928. [CrossRef]

2. Mayer, P.; Kaczmar, J. Właściwości i Zastosowania Włókien Węglowych i Szklanych. Tworzywa Sztuczne i Chemia 2008, 6, 52-56.

3. Aidy Ali, Z.; Shaker, R.; Khalina, A.; Sapuan, S.M. Development of Anti-Ballistic Board from Ramie Fiber. Polym.-Plast. Technol. Eng. 2011, 50, 622-634. [CrossRef]

4. Yeung, K.K.H.; Rao, K.P. Mechanical Properties of Kevlar-49 Fibre Reinforced Thermoplastic Composites. Polym. Polym. Compos. 2012, 20, 411-424. [CrossRef]

5. Manigandan, S. Determination of Fracture Behavior under Biaxial Loading of Kevlar 149. Appl. Mech. Mater. 2015, 766-767, 1127-1132. [CrossRef]

6. Krishan, P.; Purna, S. Basalt Fiber and Its Composites: An Overview. In Proceedings of the National Conference on Advances in Structural Technologies, Silchar, India, 1-3 February 2019.

7. Qui, Y.; Schwartz, P. Micromechanical behavior of Kevlar-149/S-glass hybrid seven-fiber microcomposites: I. Tensile strength of the hybrid composite. Compos. Sci. Technol. 1993, 47, 289-301. [CrossRef]

8. Al-Kheetan, M.J.; Rahman, M.M.; Balakrishna, M.N.; Chamberlain, D.A. Performance Enhancement of Self-Compacting Concrete in Saline Environment by Hydrophobic Surface Protection. Can. J. Civ. Eng. 2019, 46, 677-686. [CrossRef]

9. Katzer, J.; Kobaka, J.; Ponikiewski, T. Influence of Crimped Steel Fibre on Properties of Concrete Based on an Aggregate Mix of Waste and Natural Aggregates. Materials 2020, 13, 1906. [CrossRef]

10. Kostrzanowska-Siedlarz, A.; Gołaszewski, J. Rheological Properties of High Performance Self-Compacting Concrete: Effects of Composition and Time. Constr. Build. Mater. 2016, 115, 705-715. [CrossRef]

11. Maria Cruz, A.; Javier, P. Self-Compacted Concrete with Self-Protection and Self-Sensing Functionality for Energy Infrastructures. Materials 2020, 13, 1106. [CrossRef]

12. Biolzi, L.; Cattaneo, S. Response of steel fiber reinforced high strength concrete beams: Experiments and code predictions. Cem. Concr. Compos. 2017, 1-13. [CrossRef]

13. Ostrowski, K. The influence of CFRP sheets on the strength of specimens produced using normal concrete and high-performance concrete assessed using uniaxial compression tests. Tech. Trans. 2017, 7, 41-51. [CrossRef]

14. Ostrowski, K.; Kinasz, R.; Cieślik, J.; Wałach, D.; Ahmida, B. Nośność Elementów Osiowo Ściskanych na Przykładzie Kolumn z Betonu i Fibrobetonu Wysokowartościowego Wzmocnionych Włóknami Węglowymi. Czasopismo Inżynierii Ląowej Środowiska i Architektury. 2016, 63, 309-316. [CrossRef] 
15. Glinicki, M. Beton ze Zbrojeniem Strukturalnym; XXV Ogólnopolskie warsztaty pracy projektanta konstrukcji: Szczyrk, Poland, 2010.

16. Karwowska, J.; Łapko, A. Przydatność Stosowania Nowoczesnych Kompozytów Fibrobetonowych w Konstrukcjach Budowlanych. Budownictwo i Inżynieria Środowiska. 2011, 2, 2081-3279.

17. Mesba, H.A.; Buyle-Bodin, F. Efficiency of polypropylene and metallic fibres on control of shrinkage and cracking of recycled aggregate mortars. Constr. Build. Mater. 1999, 13, 439-447. [CrossRef]

18. Leda, H. Szklane czy Węglowe Włókna w Kompozytach Polimerowych. Kompozyty 2003, 3, $209-215$.

19. Kobets, L.P.; Deev, I.S. Carbon fibres: Structure and mechanical properties. Compos. Sci. Technol. 1997, 57, 1571-1580. [CrossRef]

20. Abdelrahman, K.; El-Hacha, R. Cost and Ductility Effectiveness of Concrete Columns Strengthened with CFRP and SFRP Sheets. Polymers 2014, 6, 1381-1402. [CrossRef]

21. Ostrowski, K.; Kinasz, R.; Cieślik, J.; Wałach, D. The influence of CFRP sheets on strength of short columns produced from normal strength concrete and fibre reinforced concrete. Tech. Trans. Civ. Eng. 2016. [CrossRef]

22. Biolzi, L.; Cattaneo, S. Assessment of historical masonry pillars reinforced by CFRP strips. AIP Conf. Proc. 2014, 1618, 630. [CrossRef]

23. Carolin, A. Carbon Fibre Reinforced Polymers for Strengthening of Structural Elements. Ph.D. Thesis, Lulea University of Technology, Lulea, Sweden, 2003; 194p.

24. Campione, G.; Miraglia, N. Strength and strain capacities of concrete compression members reinforced with FRP. Cem. Concr. Compos. 2003, 25, 31-41. [CrossRef]

25. Koosha, K.; Pedram, S. Performance of high-modulus near-surface-mounted FRP laminates for strengthening of concrete columns. Compos. Part B 2019, 164, 90-102. [CrossRef]

26. Rajai, Z.; Al-Rousan, M.H.B. Impact of curvature type on the behaviour of slender reinforced concrete rectangular column confined with CFRP composite. Compos. Part B 2019, 173, 106939. [CrossRef]

27. Mohammed, A.Z.; Hayder, A.R.; Alkhrdaji, T. Performance of CFRP-strengthened concrete beams fastened with distributed CFRP dowel and fiber anchors. Compos. Part B 2019, 176, 107117. [CrossRef]

28. Huifeng, Z.; Jin, W.; Fengyu, J.; Chengjun, Z. Effect of corroded tension reinforcements on flexural performance of reinforced recycled aggregate concrete beams strengthened with CFRP. Compos. Part B 2019, 162, 589-599. [CrossRef]

29. Kissman, V.; Sundar, L. An experimental study on strengthening of RC column with GFRP. Mater. Today Proc. 2019. [CrossRef]

30. Sadeghian, P.; Fillmore, B. Strain distribution of basalt FRP-wrapped concrete cylinders. Case Stud. Constr. Mater. 2018, 9, e00171. [CrossRef]

31. Campione, G.; La Mendola, L.; Monaco, A.; Valenza, A.; Fiore, V. Behavior in compression of concrete cylinders externally wrapped with basalt fibers. Compos. Part B Eng. 2015, 69, 576-586. [CrossRef]

32. Toutanji, H.; Deng, Y. Strength and durability performance of concrete axially loaded members confined with AFRP composite sheets. Compos. Part B Eng. 2011, 33, 255-261. [CrossRef]

33. Eid, R.; Paultre, P. Compressive behavior of FRP-confined reinforced concrete columns. Eng. Struct. 2017, 132, 518-530. [CrossRef]

34. Cascardi, A.; Longo, F.; Micelli, F.; Aiello, M.A. Compressive strength of confined column with Fiber Reinforced Mortar (FRM): New design-oriented-models. Constr. Build. Mater. 2017, 156, 387-401. [CrossRef]

35. Bencardino, F.; Nisticò, M.; Verre, S. Experimental Investigation and Numerical Analysis of Bond Behavior in SRG-Strengthened Masonry Prisms Using UHTSS and Stainless-Steel Fibers. Fibers 2020, 8, 8. [CrossRef]

36. Wang, X.; Liu, L.; Shen, W.; Zhou, H. CFRP Reinforced Foam Concrete Subjected to Dynamic Compression at Medium Strain Rate. Materials 2020, 13, 10. [CrossRef] [PubMed]

37. Ostrowski, K.; Dudek, M.; Sadowski, Ł. Compressive behaviour of concrete-filled carbon fiber-reinforced polymer steel composite tube columns made of high performance concrete. Compos. Struct. 2019, 111668. [CrossRef]

38. Ostrowski, K. Does the Carbon Fibre Coating Reinforcement Have an Influence on the Bearing Capacity of High-Performance Self-Compacting Fibre-Reinforced Concrete? Materials 2019, 12, 4054. [CrossRef] [PubMed]

39. Al-Abdwais, A.; Al-Abdwais, R. Modified cement-based adhesive for near-surface mounted CFRP strengthening system. Constr. Build. Mater. 2016, 124, 794-800. [CrossRef] 
40. Cruz, J.R.; Serega, S.; Sena-Cruz, J.; Pereira, E.; Kwiecień, A.; Zając, B. Flexural behaviour of NSM CFRP laminate strip systems in concrete using stiff and flexible adhesives. Compos. Part B Eng. 2020, 195, 108042. [CrossRef]

41. Azevedo, A.S.; Firmo, J.P.; Correia, J.R.; Tiago, C. Influence of elevated temperatures on the bond behaviour between concrete and NSM-CFRP strips. Cem. Concr. Compos. 2020, 111, 103603. [CrossRef]

42. Yang, X.; Gao, W.Y.; Dai, J.G.; Lu, Z.D.; Yu, K.Q. Flexural strengthening of RC beams with CFRP grid-reinforced ECC matrix. Compos. Struct. 2018, 189, 9-26. [CrossRef]

43. Yin, Y.; Fan, Y. Influence of Roughness on Shear Bonding Performance of CFRP-Concrete Interface. Materials 2018, 11, 1875. [CrossRef]

44. Stark, A.; Classen, M.; Hegger, J. Bond behaviour of CFRP tendons in UHPFRC. Eng. Struct. 2019, 178, 148-161. [CrossRef]

45. Polish Committee for Standardization. PN-EN 12350-8:2009, Testing Fresh Concrete-Part 8: Self-Compacting Concrete-Slump Flow Test; Polish Committee for Standardization: Warszawa, Poland, 2009. (In Polish)

46. Polish Committee for Standardization. PN-EN 12390-3:2009, Testing Hardened Concrete. Compressive Strength of Test Specimens; Polish Committee for Standardization: Warszawa, Poland, 2009. (In Polish)

47. Czarnecki, S.; Hoła, J.; Sadowski, Ł. A nondestructive method of investigating the morphology of concrete surfaces by means of newly designed 3D scanner. In Proceedings of the 1th European Conference on Non-Destructive Testing (ECNDT 2014), Prague, Czech Republic, 6-10 October 2014.

48. Zaleski, K.; Matuszak, J.; Zaleski, R. Metrologia Warstwy Wierzchniej; Wydawnictwo Politechniki Lubelskiej: Lublin, Poland, 2018.

49. Cybo, J.; Gołąb, A.; Służałek, G. Badania struktury geometrycznej warstwy wierzchniej metodą 3D. In Solidification of Metals and Alloys; Book No. 44 Krzepnięcie Metali i Stopów, Rok 2000, Rocznik 2; Nr 44Polska Akademia Nauk: Katowice, Poland, 2000; Volume 2, ISSN 0208-9386.

50. Salcedo, M.C.; Coral, I.B.; Ochoa, G.V. Characterization of Surface Topography with Abbott Firestone Curve. Contemp. Eng. Sci. 2018, 11, 3397-3407. [CrossRef]

51. Lawrence, K.D.; Shanmugamani, R.; Ramamoorthy, B. Evaluation of image based Abbott-Firestone curve parameters using machine vision for the characterization of cylinder liner surface topography. Measurement 2014, 55, 318-334. [CrossRef]

(C) 2020 by the authors. Licensee MDPI, Basel, Switzerland. This article is an open access article distributed under the terms and conditions of the Creative Commons Attribution (CC BY) license (http://creativecommons.org/licenses/by/4.0/). 